\title{
Game Analysis on Lowering Price Maliciously between Farmers and Grain Merchants under the Background of Repayment Pressure
}

\author{
Dehua Zhang ${ }^{1, \mathrm{a} *}$ \\ ${ }^{1}$ Harbin University of Commerce, Harbin China 150028 \\ azdh19841027@163.com
}

Keywords: Lower price; Farmers; Grain merchants; Competition mechanism; Storage costs

\begin{abstract}
In remote areas, grain sales of the farmers depend on the grain merchants. In the process of the sales, the grain merchants will lower the price which plays a direct role in farmers' grain income and restricts the grain production enthusiasm of farmers. The paper analyzes the game behaviors between farmers and grain merchants using complete information dynamic game model, then comes to the conclusion that competition mechanism and storage costs have a direct impact on the behaviors between farmers and grain merchants.
\end{abstract}

\section{Introduction}

In the survey, farmers generally reflect that the grain merchants will lower the grain price in the forthcoming repayment which causes unreasonable economic losses for farmers. In order to analyze clearly interest consideration and specific strategies between grain merchants and farmers in the process of the game, the paper discusses them using the game model.

\section{Game Model Selection}

The grain merchants and the farmers know each other's strategies very well and can expect the other's strategies basically ${ }^{[1]}$. What's more, the farmers always choose the relevant strategies after knowing the strategies of grain merchants. Therefore, such kind of game complies with complete information dynamic game and this part discusses them using dynamic game mode $1^{[2]}$.

\section{Game Analyses on Grain Merchants without Competitors}

\section{The Extended Shape of Game Model.}

The subjects of the game are the grain merchants and farmers. This part focuses on the game process between a grain merchant and a farmer [3]. The grain merchants aim at profit maximum. The farmers want to resolve repayment pressure and it must be solved on time. Therefore, game subject specific strategies are as follows:

(a) The strategy set of grain merchants is \{lower price for purchase, purchase with integrity

(b) The strategy set of farmers is \{ sell grain immediately, waiting for the price to sell\}

As the following table is shown, the solid frame represents the game subject; the virtual frame represents the specific strategies of the game subject. According to the selection order and strategy set on both sides of game, the paper describes specific game information using dynamic game-shaped extensions. When the grain merchants lower the price to purchase, the farmers have two choices, including selling grain immediately and waiting for the price to sell. When the grain merchants purchase the grain with integrity, the farmers choose to sell the grain immediately, because the purchasing price is reasonable at the market combined with farmers' repayment pressure. See the details are as follows: 


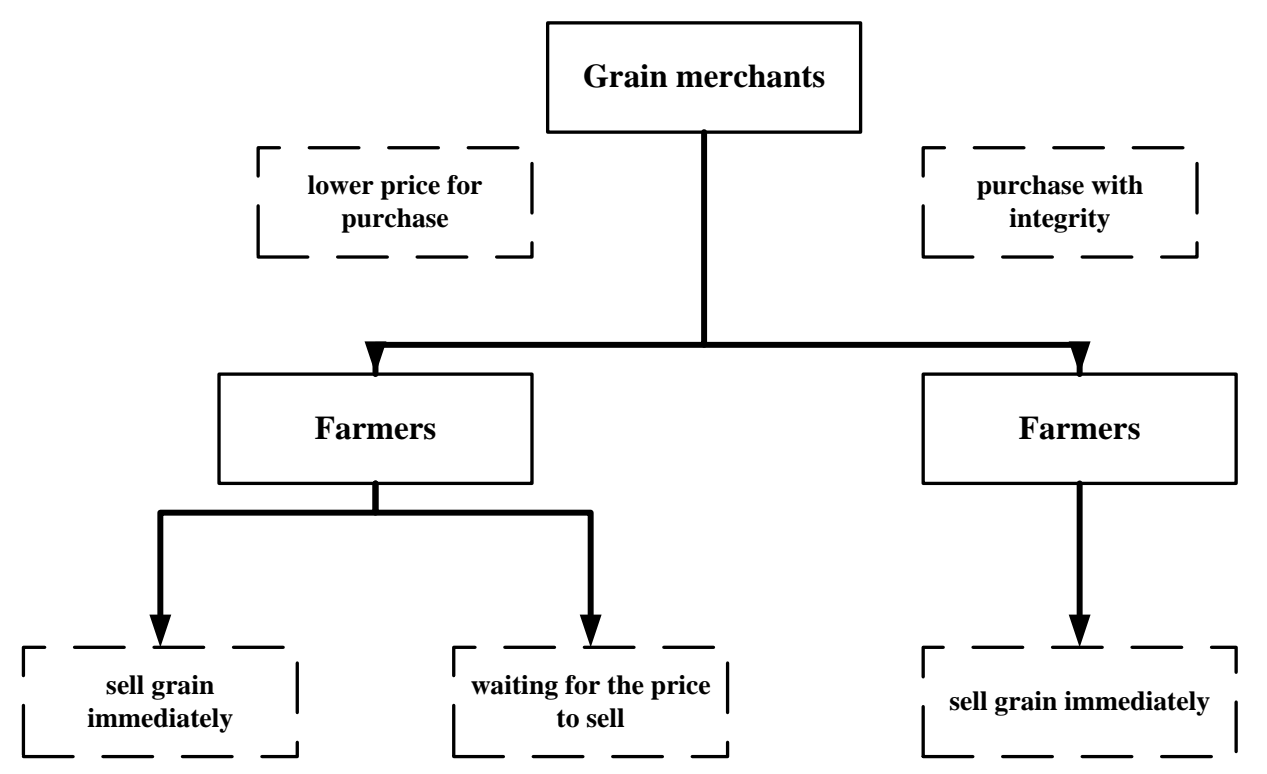

Figure 1 the game extended shape between grain merchants and farmers

\section{Relevant Earnings Analysis on Game Subjects.}

In order to analyze the game process between grain merchants and the farmers, we should know about the earning situations with different strategies [4]. In order to analyze briefly the game process of lowering the price maliciously, the paper makes the following assumptions:

Assumption 1: Grain purchasing from grain merchants has certain geographical restrictions. That is, grain merchants purchase grain in fixed town [5].

Assumption 2: Whether or not to buy the grain, the grain merchants should pay certain costs ahead of time in order to purchase the grain.

Assumption 3: The farmers need money to repay the loan, so no matter what choices they choose, they will repay the loan on time [6].

Assumption 4: The farmers have to sell all the agricultural products at one time.

Assuming that the farmers possess the products $\mathrm{Q}$ and the market price of grain is PF. The market price is made by the grain merchants and the price is not lowered maliciously by them. The grain production cost of farmers is $\mathrm{C}$. when the farmers sell the grain with equal price, the increasing storage cost is CF1(t) and the cost of borrowing money to repay for farmers is CF2(t). Among them, $t$ is the time of the grain unsold and these two functions are monotonically increasing ones. Assuming that the grain merchants sell the grain at the price of PS and this is the price of grain purchasing. Lowering the price maliciously by the merchants is $\Delta \mathrm{P}$ per unit. The fixed grain cost of the merchants is CS1. The changing cost of merchants purchasing grain is CS2. The time cost of merchants is $\mathrm{CS}(\mathrm{t})$ and the function is monotonically increasing one.

Table 1 Strategy selection and earnings on both sides

\begin{tabular}{|c|c|c|}
\hline $\begin{array}{c}\text { grain merchants } \\
\text { farmers }\end{array}$ & lowering the price & purchasing with integrity \\
\hline sell immediately & $\left(\mathrm{F}\left(\mathrm{x}_{1}\right), \mathrm{F}\left(\mathrm{y}_{1}\right)\right)$ & $\left(\mathrm{F}\left(\mathrm{x}_{3}\right), \mathrm{F}\left(\mathrm{y}_{3}\right)\right)$ \\
\hline $\begin{array}{c}\text { waiting for the price } \\
\text { to sell }\end{array}$ & $\left(\mathrm{F}\left(\mathrm{x}_{2}\right), \mathrm{F}\left(\mathrm{y}_{2}\right)\right)$ & \\
\hline
\end{tabular}


Among them, $\mathrm{F}(\mathrm{x})$ represents farmers' earnings function; $\mathrm{F}(\mathrm{y})$ represents earnings function of grain merchants. Using different strategies, the specific earnings gained by grain merchants and farmers are as follows:

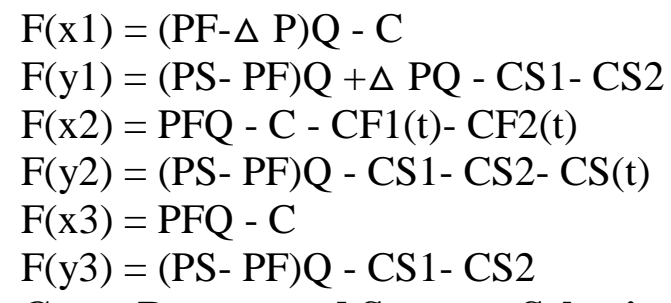

Game Process and Strategy Selection.

To compare $\mathrm{F}(\mathrm{x} 1)$ with $\mathrm{F}(\mathrm{x} 2), \mathrm{F}(\mathrm{x} 1)-\mathrm{F}(\mathrm{x} 2)=\mathrm{CF} 1(\mathrm{t})+\mathrm{CF} 2(\mathrm{t})-\Delta \mathrm{PQ}$. Among them, $\mathrm{CF} 1(\mathrm{t})+\mathrm{CF} 2(\mathrm{t})$ is positive and $\Delta \mathrm{PQ}$ is positive, too. When CF1(t)+CF2(t) $>\Delta \mathrm{PQ}$, it shows that $\mathrm{F}(\mathrm{x} 1)$ is more than $\mathrm{F}(\mathrm{x} 2)$. Then the farmers will sell the grain immediately and its corresponding earnings function of grain merchants is $\mathrm{F}(\mathrm{y} 1)$. When the merchants purchase the grain with integrity, the farmers will sell the grain immediately. Therefore, comparing $F(y 1)$ with $F(y 3), F(y 1)-F(y 3)=$ $\Delta \mathrm{PQ} . \Delta \mathrm{PQ}$ is more than 0 , so $\mathrm{F}(\mathrm{y} 1)$ is more than $\mathrm{F}(\mathrm{y} 3)$. Then the merchants will lower the price and we can come to the conclusion that sub-game perfect Nash equilibrium is lower price for purchase, sell grain immediately .

When $\mathrm{CF} 1(\mathrm{t})+\mathrm{CF} 2(\mathrm{t})<\Delta \mathrm{PQ}$, it shows $\mathrm{F}(\mathrm{x} 1)$ is less than $\mathrm{F}(\mathrm{x} 2)$. Then the farmers will wait for the price to see and its corresponding earnings function of grain merchants is $F(y 2)$. When the merchants purchase the grain with integrity, the farmers will sell the grain immediately. Therefore, comparing $\mathrm{F}(\mathrm{y} 2)$ with $\mathrm{F}(\mathrm{y} 3), \mathrm{F}(\mathrm{y} 2)-\mathrm{F}(\mathrm{y} 3)=-\mathrm{CS}(\mathrm{t})$. - $\mathrm{CS}(\mathrm{t})$ is less than ), so $\mathrm{F}(\mathrm{y} 2)$ is less than $\mathrm{F}(\mathrm{y} 3)$. According to backward induction, we can come to the conclusion that sub-game perfect Nash equilibrium is \{purchasing with integrity, sell grain immediately\}.

\section{Game Analyses on Grain Merchants with Competitors}

\section{The Extended Shape of Game Model.}

In the process of game, the grain merchants choose to lower the price. The subjects of the game are the grain merchants and farmers. Meanwhile, the grain merchants have some competitors and the farmers can adjust the price with negotiation. Under this premise, the grain merchants aim at profit maximum. The farmers want to resolve repayment pressure and it must be solved on time. Therefore, game subject specific strategies are as follows:

(a) The strategy set of grain merchants is \{lower price for purchase, accept price adjustment, refuse price adjustment $\}$

(b) The strategy set of farmers is \{endure, price adjustment with negotiation, sell grain immediately, waiting for the price to sell $\}$ 

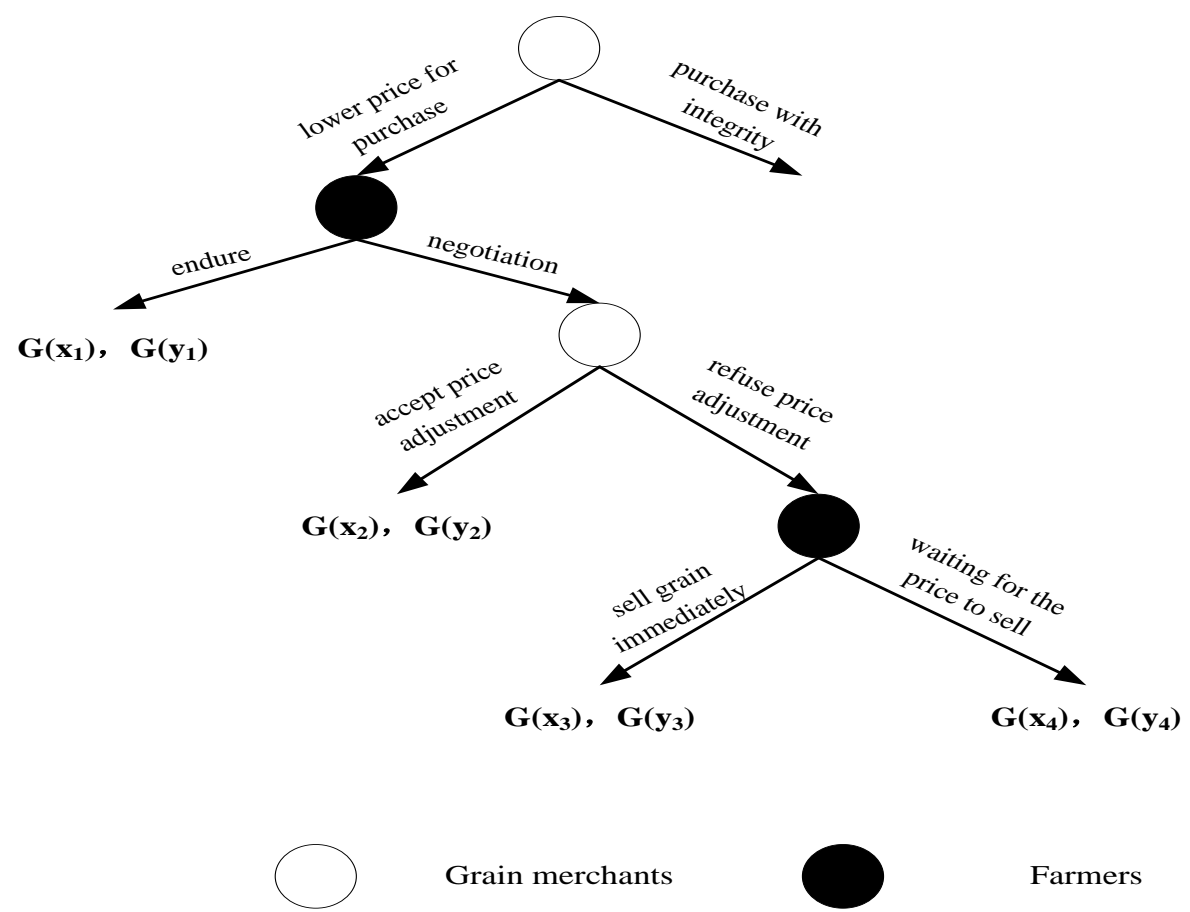

Figure 2. The game extended shape between grain merchants and farmers

\section{Relevant Earnings Analysis on Game Subjects.}

In order to analyze the game process between grain merchants and the farmers, we should know about the earning situations with different strategies. In order to analyze briefly the game process of lowering the price maliciously, the paper makes the following assumptions:

Assumption 1: The grain merchants have some competitors

Assumption 2: Whether the merchants purchase the grain or not, they will pay for some costs ahead of time.

Assumption 3: The farmers need money to repay the loan, so no matter what choices they choose, they will repay the loan on time.

Assumption 4: The farmers have to sell all the agricultural products at one time.

Assumption 5: When the farmers sell the grain immediately, they must sell the grain to the merchants.

Assuming that the negotiating cost of farmers is $\mathrm{C}^{\prime}$, they increase the price $\Delta \mathrm{P}^{\prime}, \Delta \mathrm{P}^{\prime}$ is more than 0 and is less than $\Delta \mathrm{P}$. If the farmers wait for the price to sell, the probability of selling grain to the competitors is $\rho$ which is between 0 and 1 . If $G(x)$ represents profit function of farmers, $G(y)$ represents profit function of merchants, then using different strategies, the specific earnings gained by grain merchants and farmers are as follows:

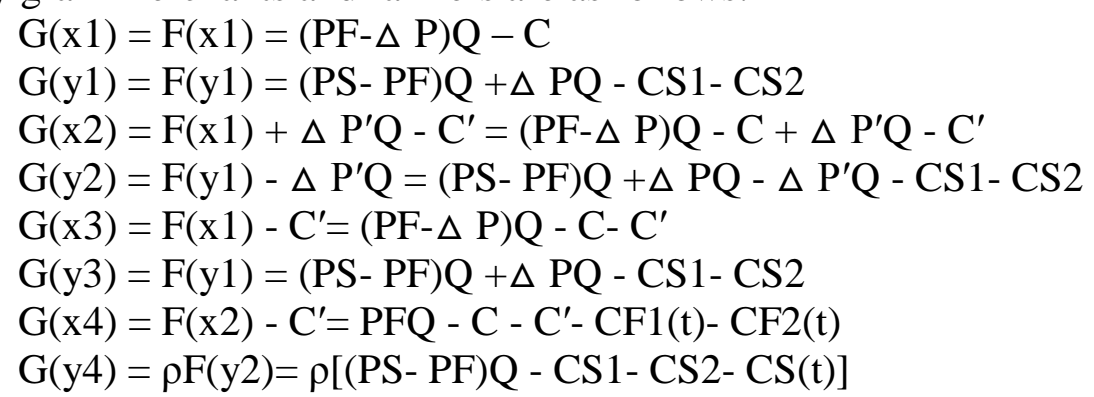

\section{Game Process and Strategy Selection.}

When $\mathrm{CF} 1(\mathrm{t})+\mathrm{CF} 2(\mathrm{t})>\triangle \mathrm{PQ}, \mathrm{G}(\mathrm{x} 3)$ is more than $\mathrm{G}(\mathrm{x} 4)$. Comparing $\mathrm{G}(\mathrm{x} 3)$ with $\mathrm{G}(\mathrm{x} 4)$, $\mathrm{G}(\mathrm{x} 3)-\mathrm{G}(\mathrm{x} 4)=\mathrm{CF} 1(\mathrm{t})+\mathrm{CF} 2(\mathrm{t})-\triangle \mathrm{PQ}$, the farmers will sell the grain immediately and its corresponding earnings function of grain merchants is $G(y 3)$. Comparing $G(y 3)$ and $G(y 2)$, $\mathrm{G}(\mathrm{y} 3)-\mathrm{G}(\mathrm{y} 2)=\Delta \mathrm{P}^{\prime} \mathrm{Q}, \quad \Delta \mathrm{P}^{\prime} \mathrm{Q}$ is more than 0 , so $\mathrm{G}(\mathrm{y} 3)$ is more than $\mathrm{G}(\mathrm{y} 2)$ and the merchants will refuse to adjust the price and its corresponding earnings function of farmers is $G(x 3)$. Comparing 
$\mathrm{G}(\mathrm{x} 3)$ with $\mathrm{G}(\mathrm{x} 1), \mathrm{G}(\mathrm{x} 1)-\mathrm{G}(\mathrm{x} 3)=\mathrm{C}^{\prime}, \mathrm{G}(\mathrm{x} 1)$ is more than $\mathrm{G}(\mathrm{x} 3)$, so the farmers will endure the price. Then sub-game perfect Nash equilibrium is \{lower price for purchase, refuse price adjustment and \{endure, price adjustment with negotiation, sell grain immediately\}.

When $C F 1(t)+C F 2(t)<\Delta P Q, G(x 3)$ is less than $G(x 4)$, the farmers will wait for the price to sell the grain and its corresponding earnings function of grain merchants is $G(y 4)$. Comparing $G(y 4)$

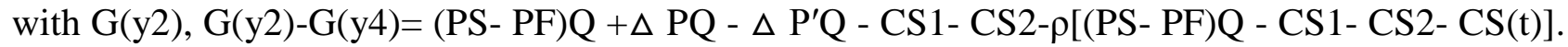
$P$ is between 0 and 1 , if $\rho$ is 1 , the farmers will sell the grain to the grain merchants, not the competitors, then $\mathrm{G}(\mathrm{y} 2)-\mathrm{G}(\mathrm{y} 4)=\Delta \mathrm{PQ}-\Delta \mathrm{P}^{\prime} \mathrm{Q}+\mathrm{CS}(\mathrm{t})$. The farmers can't raise the price too high, but to reduce the losses, so $\Delta \mathrm{P}>\Delta \mathrm{P}^{\prime}$ and $\Delta \mathrm{PQ}-\Delta \mathrm{P} \mathrm{P}^{\prime}+\mathrm{CS}(\mathrm{t})$ is more than 0 . It shows that $\mathrm{G}(\mathrm{y} 4)$ takes a maximum value, that is, $\mathrm{G}(\mathrm{y} 2)>\mathrm{G}(\mathrm{y} 4)$, the merchants will accept the price adjustment and its corresponding earnings function of farmers is $G(x 2)$. Comparing $G(x 2)$ with $G(x 1)$, $\mathrm{G}(\mathrm{x} 2)-\mathrm{G}(\mathrm{x} 1)=\Delta \mathrm{P}^{\prime} \mathrm{Q}-\mathrm{C}^{\prime}$. The negotiationg is initiated by the farmers and the cost is relatively small, such as telephone interviews, so $\Delta \mathrm{P}^{\prime} \mathrm{Q}-\mathrm{C}^{\prime}$ is more than 0 and $\mathrm{G}(\mathrm{x} 2)$ is more than $\mathrm{G}(\mathrm{x} 1)$, then the farmers will tend to adjust the price with negotiation. The sub-game perfect Nash equilibrium is \{lower price for purchase, accept price adjustment\} and \{price adjustment with negotiation, waiting for the price to sell \}.

\section{Conclusions}

Through the game analysis, we get to the conclusion that the grain merchants will lower the price easily without competitors [7-9]. If there are some competitors, the grain merchants will focus on the requirements of farmers. Or the farmers will sell the grain to the competitors. In addition, the strategy selection and the loss of lowering the price $\triangle \mathrm{PQ}$ for farmers have a direct relation with the cost of waiting for the price $\mathrm{CF} 1(\mathrm{t})+\mathrm{CF} 2(\mathrm{t})$. As long as the transaction cost is less than the benefit loss at present, that is, the farmers reduce the loss as much as possible and they will wait for the price to sell the grain [10].

\section{Acknowledgment}

The paper is the phase progress of PhD Research Project Started of Harbin University of Commerce (14RW10); this paper is supported by Science Research Foundation of Northeast Agricultural University (item number 2012RCB77); this paper is the phase progress of Philosophy and Social Science Project of Ministry of Education "Research on the Mechanism Innovation of Rural Land Transfer and Its Efficiency \& Income Distribution (item number 14YJC790125)"

\section{References}

[1] Qiao Xuhua, Zhang Jianjie. Behavior orientation and policy effect of grain operation in main grain producing areas based on investigation in Henan [J]. Research of Agricultural Modernization, 2008, 29(2):142-145

[2] Jiang Jinqi, Zhao Hui. Agricultural price fluctuation and stable farmers' income in main grain producing areas [J]. Agricultural Economy, 2008(12): 93 94

[3] Zhang Dehua, Zhou Huiqiu and Lou Sha. The problems and the countermeasures in food production in Heilongjiang [J]. Research of Agricultural Modernization. 2012(4):411-414

[4] Lou Sha, Liu Huiping, Zhang Dehua. Comparative study on grain production and farmers' income coordination in Heilongjiang [J]. Research of Agricultural Modernization. 2013, Vol.34 (6):654-658

[5] Wang Peigang. Analysis on game path benefit subjects in current land expropriation [J]. Issues in Agricultural Economy, 2007(10):34-40 
[6] Zhang Dehua. Study on influential factors and countermeasures of farmers' income in Heilongjiang [D]. Harbin: Northeast Agricultural University, 2013

[7] Wei Baolong, Li Jing. Influence on farmers' income by social capital and human capital within the agricultural industry cluster [J] Issues in Agricultural Economy, 2014 (12): 41 - 47

[8] Ding Wen'en. New ways to increase farmers' income: to give people empowerment [J] Agriculture Economy 2011(11) 64-67.

[9] Jiao Jiang and other. Rural economic development and farmers' income growth [M] Beijing: China Agriculture Press, 2008

[10]Zhou Wenhai,Zhao Guiling, Yin Chengyuan, Dynamic study on farmers' income influenced by the development of agricultural insurance--based on the empirical test of the panel system GMM model[J] Insurance Studies, 2014 (5): 21-30 